\title{
Reasons To Not Frequent The Prenatal Care: An Ethnographic Study In a Low Income Community
}

\author{
Rosa, Patricia Lima Ferreira Santa; Hoga, Luíza Akiko Komura \\ Escola de Enfermagem da USP — patriciasantarosa@usp.br
}

Introduction: To know why the pregnant women do not search for prenatal care is important to guide the practitioners and the public policies. Objectives: This study aimed to understand the reasons of not accessing prenatal care according to the women's perspectives. Methods: The research approach was qualitative and an ethnography was done in a low income community located close to a Primary Health Care Unit of Cotia and Vargem Grande Paulista cities, located within the Metropolitan Area of Sao Paulo. The participant observation method was done and eleven women living in the community were interviewed. Results: Three cultural descriptors and a cultural theme were elaborated. 1) The delay in realizing the pregnancy resulted in failure to achieve prenatal care; 2) The need to overcome many obstacles to access the prenatal care that is not good neither indispensable contributed to the no realization of prenatal; 3 ) The prenatal care was not accessed because we must hide the pregnancy to not be punished. The cultural theme was "Not worth the strong effort to access a prenatal care that is not good". Discussion: The self perception as a pregnant woman not occurs immediately among these women. Several obstacles hindered their access to prenatal. The low quality of services was seen as an important reason to not access the prenatal care. The idea internalized by women that the public health services are not good has contributed for the adoption of this behavior. Another barrier was the lack of family and social support to access the prenatal care. Conclusion: The low income women have a particular way to see and behave towards their own health care practices. The Family Health Program (FHP) is not available for most of the women living in the studied community. The administrative practices and the quality of prenatal care should be improved to transform the negative imagery prevailing among the women. The informants of this study have reported the existence of several needs in women's health scope that should be attended by health care providers.

Rosa, Patricia Lima Ferreira Santa; Hoga, Luíza Akiko Komura. Reasons To Not Frequent The Prenatal Care: An Ethnographic Study In a Low Income Community. In: Anais do Congresso Internacional de Humanidades \& Humanização em Saúde [= Blucher Medical Proceedings, num.2, vol.1]. São Paulo: Editora Blucher, 2014. ISSN 2357-7282

DOI 10.5151/medpro-cihhs-10371 